УДК 611.724.013.018-053.15-053.31

DOI: $10.24061 / 1727-0847.17 .4 .2018 .6$

\author{
D.B. Stoliar, O.M. Slobodian, L.P. Lavriv, M.P. Kavun
}

Higher State Educational Establishment of Ukraine "Bukovinian State Medical University”, Chernivtsi City

\title{
TOPOGRAPHIC-ANATOMICAL PECULIARITIES OF THE TEMPOROMANDIBULAR JOINT IN THE THIRD TRIMESTER OF THE INTRAUTERINE DEVELOPMENT AND NEONATES
}

\section{ТОПОГРАФОАНАТОМІЧН ОСОБЛИВОСТІ СКРОНЕВО-НИЖНЬОЩЕЛЕПНОГО СУГ- ЛОБА В ТРЕТЬОМУ ТРИМЕСТРІ ВНУТРІШНЬОУТРОБНОГО РОЗВИТКУ ТА НОВОНАРО- ДЖЕНИХ}

Резюме. Незважаючи на певний прогрес та інтенсивний розвиток стоматологічних технологій, досі існує безліч нез'ясованих питань щодо будови елементів зубощелепної системи. Аномалії розвитку скронево-нижньощелепного суглоба сприяють змінам обрису або розвитку деформації лиця, дегенерації або гіпертрофії жувальних та мімічних м'язів, порушують ковтальні та жувальні рухи, прикус або оклюзію. Дослідження проведено на 19 препаратах плодів 301,0-450,0 мм тім'яно-п'яткової довжини та 6 препаратах новонароджених методами морфометрії та краніометрії, макро- та мікропрепарування, комп'ютерної томографії та статистичного аналізу. Більшість морфометричних параметрів у динаміці третього триместру зростає рівномірно. Інтенсивніше збільшуються окружність голови - на 28-му, 29му та 30-му тижнях; довжина черепа - на 28-му, 29-му та 35-му тижнях; біпарієтальний діаметр - на 30-31-му та 35-36-му тижнях. Більшість краніометричних параметрів у новонароджених збільшуються рівномірно. Дещо інтенсивніше збільшується окружність голови на 38-му тижні. У новонароджених скронево-нижньощелепний суглоб набуває дефінітивних рис будови, характеризується наявністю незначно ввігнутої суглобової ямки та вираженого суглобового горбика. В ранньому неонатальному періоді спостерігається збільшення всіх краніометричних показників, що свідчить про нарощування загальної кісткової маси черепа, нижньої щелепи та збільшення розмірів скронево-нижньощелепного суглоба. Подальше вивчення скронево-нижньощелепний суглоба сприятиме верифікації даних отриманих шляхом УЗД, КТ, МРТ, а також може слугувати підгрунтям для визначення критичних періодів в розвитку лицевої ділянки черепа плода людини.

Ключові слова: скронево-нижньощелепний суглоб; третій триместр; новонароджені; анатомія.

In spite of a certain progress and intensive development of dental technologies there are a number of unsolved issues concerning the dentoalveolar system structures $[1,2]$. One of its important structures is the temporomandibular joint (TMJ). Impaired development of the TMJ provokes changes of the facial contour and defects, degeneration or hypertrophy of the masticatory and mimic muscles, disorders of swallowing and chewing, and occlusion [3, 4]. A considerable number of publications in scientific literature dealing with various aspects of dental anatomy still do not sufficiently study age anatomy and morphological preconditions promoting occurrence of TMJ pathology, irrespective of their important practical value $[4,5]$. Age anatomical features of the human TMJ and dynamics of its temporal-spatial changes are fragmentary $[6,7]$.

Objective: to determine anatomical peculiarities of the TMJ in the third trimester of the intrauterine development and early neonatal period of human ontogenesis.
Material and methods. The study was conducted on 19 samples of fetuses 301,0-450,0 mm of the parietal-calcaneal length and 6 samples of neonates by means of the methods of morphometry and craniometry, macro- and micropreparation, computed tomography and statistical analysis. Parietal-calcaneal, parietal-coccygeal length, head circumference, biparietal diameter, cranial length, facial breadth and height were determined. By means of craniometry the following parameters of the mandible were determined: Bi-Co distance (transverse distance between the right and left condylar processes of the mandible), Bi-Go distance (between the right and left "gonion" points), Bi-M distance (transverse distance between the right and left genial tubercles), height of mandibular branch (distance between the body and condylar process of the mandible), mandibular body length (distance from the body to the genial tubercle lined along the inferior border of the mandible), Co-M distance (between the condylar process and genial tubercle of the mandible), Go-Po distance (between

Stoliar D.B., Slobodian O.M., Lavriv L.P., Kavun M.P., 2018 
craniometric "gonion" and "pogonion" points), mandibular angle (angle between the inferior border of the mandible and posterior border of the mandibular branch), sagittal length of the mandible (distance between the middle point of Bi-Go and genial tubercle). The anterior-posterior size of the temporomandibular joint articular capsule was measured separately. Morphometric and craniometric parameters were statistically analyzed by means of the method of descriptive statistics applying computer engineering and software StatPlus (AnalystSoft, 2006). The results included into the normal distribution were processed by means of the methods of variation statistics calculating arithmetic mean $(x)$ and mean-squared error (MSE) (xS). Pearson correlation was applied to study interrelations between the parameters of the temporomandibular joint, cranio- and morphometry. $P \leq 0,05$ was considered to be statistically significant. Computed tomography method was used to measure osseous-cartilaginous elements of the skull and lower jaw as well as for objectification of the obtained results.

Results and discussion. During the $7^{\text {th }}$ month of the intrauterine development the mandibular fossa of the temporal bone is located lower from the level of the zygomatic arch, and it is formed by a thin layer of the osseous substance. Posteriorly it borders on the petrotympanic fissure, tympanic part of the temporal bone and external acoustic passage, anteriorly it borders on the articular tubercle, and laterally - on the crest of the zygomatic process of the temporal bone.

The articular disk divides the articular cavity into the upper and lower portions. The articular surface, upper and lower synovial septa are found in the articular capsule. Anteriorly the articular disk is attached to the portion of the future articular tubercle by means of the connective tissue taenia, and posteriorly - to the posterior wall of the articular capsule branching upwards and downwards. Inferiorly the articular capsule of the temporomandibular joint is attached to the mandibular neck. Lateral ligament is attached to the articular capsule. Intracapsular ligaments are poorly differentiated at this period. The articular capsule is attached to the temporal bone anteriorly in the point of the articular tubercle and further along the perimeter of the mandibular fossa to the anterior border of the petrotympanic fissure. During the period of the $8-9^{\text {th }}$ month of the intrauterine development the articular tubercle is more pronounced.

During the third trimester of the intrauterine development the head circumference (the line through the glabella, parietal tubercles and external occipital tubercle) is $291,83 \pm 28,07 \mathrm{~mm}$; biparietal diameter (between the parietal tubercles) - 77,91 $\pm 7,08 \mathrm{~mm}$; cranial length (sagittal distance between glabella and external occipital tubercle) - 95,91 $\pm 8,77 \mathrm{~mm}$; facial breadth (transverse distance between the proximal points of the zygomatic arch) $-68,58 \pm 6,14 \mathrm{~mm}$; facial height (distance between nasal point and the lowest point of the mandible) $-45,16 \pm 4,48 \mathrm{~mm}$. In neonates the head circumference is $358,75 \pm 5,37 \mathrm{~mm}$; biparietal diameter - 92,75 $\pm 1,7 \mathrm{~mm}$; cranial length $117,25 \pm 2,75 \mathrm{~mm}$; facial breadth $-87,5 \pm 3,1 \mathrm{~mm}$; facial height $-52 \pm 0,816 \mathrm{~mm}$. The parameters of craniometric examination of fetuses during the third trimester are presented in Table 1.

The majority of morphometric parameters in the dynamics of the third trimester increase evenly. More intensive increase can be detected concerning head circumference - on the $28^{\text {th }}, 29^{\text {th }}$ and $30^{\text {th }}$ weeks; cranial length - on the $28^{\text {th }}, 29^{\text {th }}$ and $35^{\text {th }}$ weeks; biparietal diameter - on the $30-31^{\text {st }}$ and $35-36^{\text {th }}$ weeks. The majority of craniometric parameters in neonates increase evenly. On the $38^{\text {th }}$ week the head circumference increases more intensively.

During the third trimester the head circumference becomes 1,35 times as much, biparietal diameter 1,32 times, cranial length $-1,36$ times, facial breadth $-1,33$ times, facial height $-1,34$ times. In neonates the head circumference becomes 1,03 times as much, biparietal diameter $-1,04$ times, cranial length $-1,05$ times, facial breadth $-1,08$ times, facial height $-1,03$ times.

Average parameters of the mandible are presented in Table 2 .

The majority of craniometric parameters of the mandible in the dynamics of the third trimester increase evenly (Figure). More intensively the following parameters increase: Bi-Co-distance - on the $25^{\text {th }}$, $29^{\text {th }}, 35^{\text {th }}$ and $36^{\text {th }}$ weeks; Bi-Go-distance - on the 25 $26^{\text {th }}$ and $35-36^{\text {th }}$ weeks; Go-Po-distance - on the $30^{\text {th }}$ and $31^{\text {st }}$ weeks. The majority of morphometric parameters of the mandible in neonates increase evenly. More intensively the following parameters increase: Bi-Co-distance - on the $38^{\text {th }}$ week; Bi-Go-distance on the $38^{\text {th }}$ and $40^{\text {th }}$ weeks; Go-Po-distance - on the $38^{\text {th }}$ week.

Anterior-posterior size of the articular capsule of the temporomandibular joint in 7-month fetuses is from 2,25 to $2,4 \mathrm{~mm}$, in 8 -month fetuses - from 2,55 to $2,8 \mathrm{~mm}$, in 9 -month fetuses - from 2,9 to $3 \mathrm{~mm}$. In the dynamics of the third trimester the anterior-posterior size of the articular capsule of the temporomandibular joint becomes 1,33 times as much.

In neonates the mandibular fossa is rather flat, it is $0,717 \pm 0,133 \mathrm{~mm}$ deep. On the surface of the mandibular fossa the osseous lamina is thickened a little compared to the previous terms of observation. The condylar process is covered with the cartilaginous tissue. The articular disk changes mainly along the way of consolidation. The middle part of the articular disk is thin: the anterior and posterior portions are thickened, and the posterior one is more thickened. The connective tissue taenia is attached to it passing fibrous strips 
upwards to the posterior clivus of the mandibular fossa, and downwards - to the neck of the condylar process. Intracapsular bonds in neonates are poorly differentiated.

Average parameters of the anterior-posterior size of the articular capsule of the temporomandibular joint in 7-month fetuses are 2,3375 $\pm 0,06$, in 8-month fetuses - 2,675 $\pm 0,11$, 9-month fetuses -
$2,9375 \pm 0,047$, and neonates $-3,5625 \pm 0,1493$.

The size of the articular capsule of the temporomandibular joint in the third trimester of the intrauterine development increases evenly. It becomes increasingly wider on the $26^{\text {th }}, 31^{\text {st }}, 32^{\text {nd }}$ and $33^{\text {rd }}$ weeks and neonates. The size of the articular capsule of the temporomandibular joint in neonates increases evenly and is from 3,4 to $3,75 \mathrm{~mm}$.

\section{Craniometric parameters of fetuses during the third trimester and neonates}

\begin{tabular}{|c|c|c|c|c|c|c|}
\hline Age, months & $\begin{array}{c}\text { Amount of } \\
\text { specimens }\end{array}$ & $\begin{array}{c}\text { Head cir- } \\
\text { cumference, } \\
\mathrm{mm}\end{array}$ & $\begin{array}{c}\text { Biparietal } \\
\text { diameter, } \\
\mathrm{mm}\end{array}$ & $\begin{array}{c}\text { Cranial } \\
\text { length, mm }\end{array}$ & $\begin{array}{c}\text { Facial } \\
\text { breadth, mm }\end{array}$ & $\begin{array}{c}\text { Facial } \\
\text { height, mm }\end{array}$ \\
\hline $7^{\text {th }}$ & 6 & $240-288$ & $68-72$ & $80-92$ & $60-64$ & $38-43$ \\
\hline $8^{\text {th }}$ & 7 & $295-301$ & $75-80$ & $94-99$ & $66-70$ & $44-47$ \\
\hline $9^{\text {th }}$ & 6 & $303-325$ & $81-90$ & $100-109$ & $71-80$ & $49-51$ \\
\hline neonates & 6 & $352-365$ & $91-95$ & $114-120$ & $84-91$ & $51-53$ \\
\hline
\end{tabular}

Table 2

Morphometric parameters of the mandible in the third trimester of the intrauterine development and

\begin{tabular}{|c|c|c|c|c|c|c|c|c|c|}
\hline \multicolumn{10}{|c|}{ neonates } \\
\hline 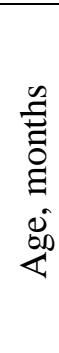 & 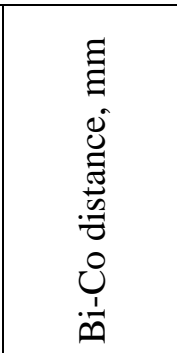 & 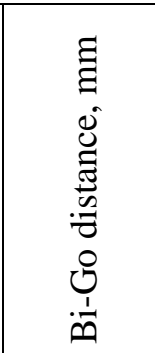 & 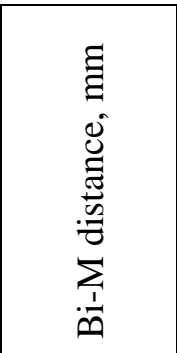 & 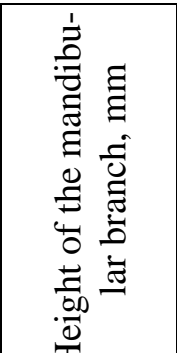 & 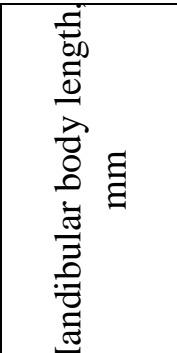 & 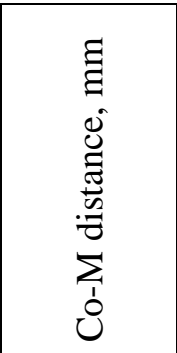 & $\begin{array}{l}\Xi \\
\Xi \\
8 \\
0 \\
\tilde{\Xi} \\
: 0 \\
0 \\
0 \\
0 \\
0\end{array}$ & 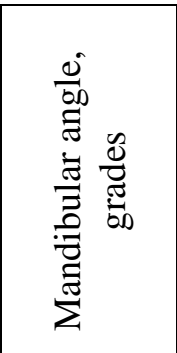 & 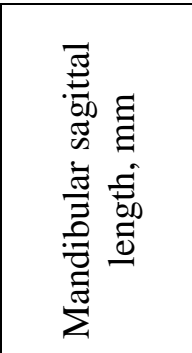 \\
\hline $7^{\text {th }}$ & $55,75 \pm 0,95$ & $44,5 \pm 1,29$ & $12,5 \pm 0,577$ & $13,75 \pm 0,95$ & $27 \pm 0,81$ & $36,75 \pm 0,95$ & $33,5 \pm 1,29$ & $123,75 \pm 3,2$ & $26,75 \pm 0,5$ \\
\hline $8^{\text {th }}$ & $61 \pm 1,73$ & $50,25 \pm 1,7$ & $15 \pm 0,81$ & $16 \pm 0,81$ & $29,5 \pm 1,29$ & $40 \pm 1,15$ & $40,25 \pm 1,7$ & $121 \pm 7,78$ & $30 \pm 1,41$ \\
\hline $9^{\text {th }}$ & $70,75 \pm 5,12$ & $60 \pm 4,76$ & $18,25 \pm 0,95$ & $18,25 \pm 0,95$ & $34,25 \pm 2,21$ & $44,75 \pm 2,75$ & $44,5 \pm 1,29$ & $134,5 \pm 6,24$ & $32,25 \pm 0,047$ \\
\hline 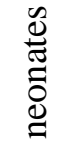 & $83 \pm 2,16$ & $73 \pm 0,81$ & $20,5 \pm 0,57$ & $21,75 \pm 0,5$ & $41,25 \pm 0,95$ & $51,5 \pm 1,29$ & $51,25 \pm 1,70$ & $122,75 \pm 1,5$ & $38 \pm 2,16$ \\
\hline
\end{tabular}

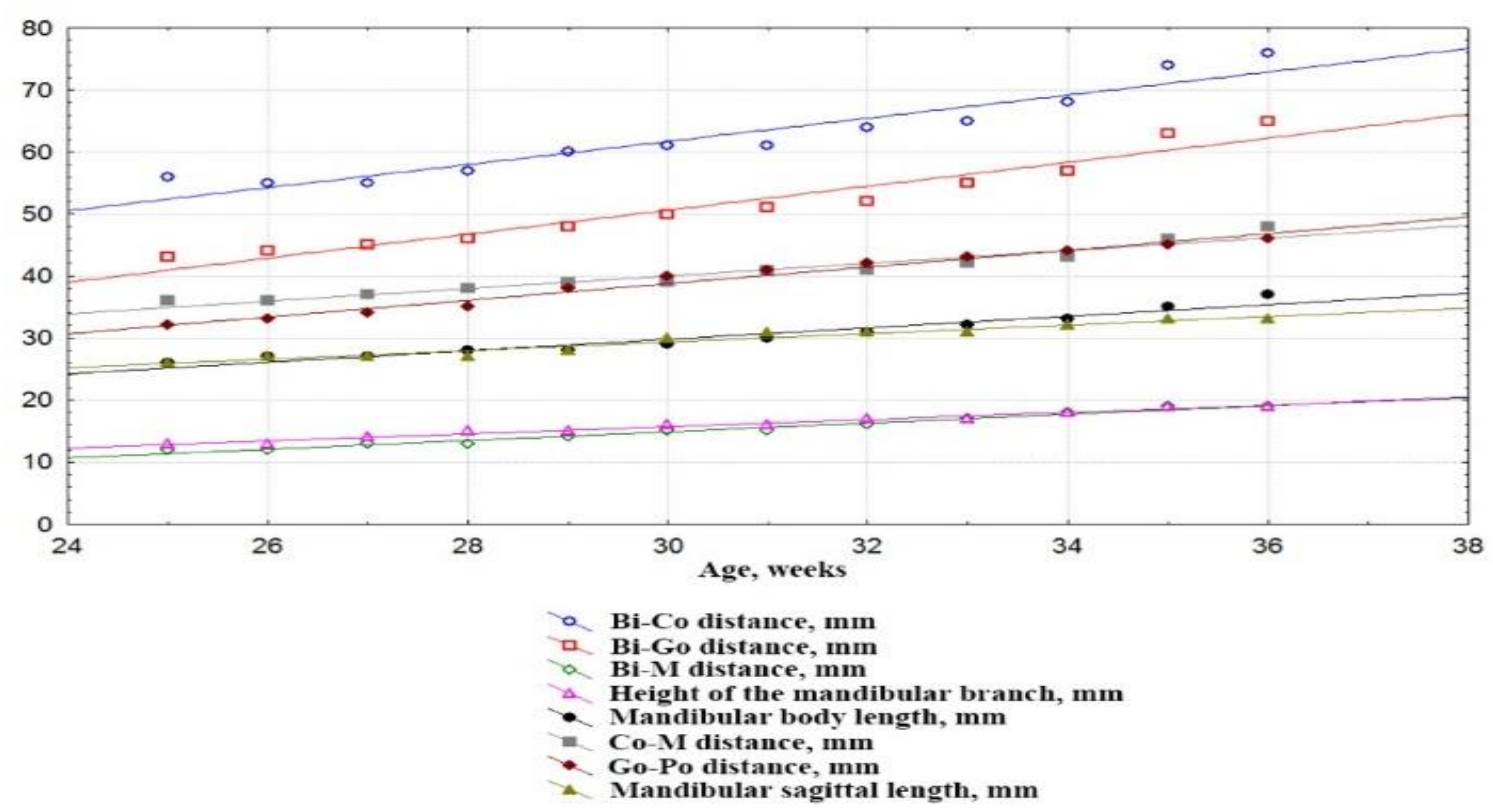

Figure. Changes of craniometric parameters of the mandible in the dynamics of the third trimester of the intrauterine development 
The correlation analysis of the morpho- and craniometric parameters depending on the anterior-posterior size of the articular capsule of the temporomandibular joint determined that in the third trimester direct strong correlation bonds are found $(r \geq 0,95)$ : the anterior-posterior size of the articular capsule of the temporomandibular joint - with the distance between the craniometric points "gonion" and "pogonion" $(\mathrm{r}=0,992)$, moderate correlation bonds - with the parameters of the head circumference $(r=0,8632)$ and Bi-M distance $(\mathrm{r}=0,8612)$, and reverse correlation with the parameters of the mandibular angle $(r=-$ 0,4802).

Direct strong correlation bonds $(r \geq 0,95)$ of the anterior-posterior size of the articular capsule of the temporomandibular joint - with the parameters of Co-M distance $(r=0,9943)$ and craniometric points "gonion" and "pogonion" ( $\mathrm{r}=0,9641)$ were detected; moderate correlation bonds - with the parameters of the mandibular body $(\mathrm{r}=0,9035)$ and parameters of Bi-M distance $(\mathrm{r}=0,87)$; weak correlation bonds- with parameters of the mandibular angle $(\mathrm{r}=0,4372)$ and parameters of the mandibular branch height $(\mathrm{r}=0,4256)$.

Therefore, analysis of the results of our own studies demonstrates that in the third trimester of the intrauterine development topographic-anatomical inter- relations of the temporomandibular joint develop rather dynamically and it occurs in close correlation with adjacent anatomical structures. The temporomandibular joint is characterized by a flat articular fossa and appearance of the articular tubercle at the 7$8^{\text {th }}$ month of the intrauterine development in the form of prominence on the inferior surface of its condylar process base.

Conclusions. In neonates the temporomandibular joint becomes of a definite structure, is characterized by slightly concave articular fossa and pronounced articular tubercle. At the early neonatal period all the craniometric parameters increase which is indicative of enlargement of general osseous cranial mass, mandible and increasing the size of the temporomandibular joint.

Prospects of further studies. Identification of correlation bonds between cranio- and morphometric parameters of fetuses and neonates with the parameters of the temporomandibular joint depending on sex is considered to be reasonable. Further study of the temporomandibular joint will promote verification of the findings obtained by means of USD, CT, MRI, and will form the basis for detection of critical periods in the development of the facial part of the human cranium in fetuses.

\section{References}

1. Çil AS, Bozkurt M, Bozkurt DK. Intrauterine temporomandibular joint dislocation: prenatal sonographic evaluation. Clin Med Res. 2014 Sep;12(1-2):58-60. doi: 10.3121/cmr.2013.1148

2. Alvez CS, Carvalho de Moraes LO, Marques SR, Tedesco RC, Harb LJ, Rodríguez-Vázquez JF, et al. Analysis by Light, Scanning, and Transmission Microscopy of the Intima Synovial of the Temporomandibular Joint of Human Fetuses during the Development. Anat Res Int. 2014;2014:732720. doi: 10.1155/2014/732720. 3. Rot I, Mardesic-Brakus S, Costain WJ, Saraga-Babic M, Kablar B. Role of skeletal muscle in mandible development. Histol Histopathol. 2014 Nov;29(11):1377-94. doi: 10.14670/HH-29.1377.

4. Roberto L. Flores. Neonatal mandibular distraction osteogenesis. Semin Plast Surg. 2014 Nov; 28(4):199206. doi: 10.1055/s-0034-1390173

5. Pahwa S, Bhalla AS, Roychaudhary A, Bhutia O. Multidetector computed tomography of temporomandibular joint: A road less travelled. World J Clin Cases. 2015 May 16;3(5):442-9. doi: 10.12998/wjcc.v3.i5.442

6. Makeyev V, Telishevska U, Kucher A. Obgruntuvannya vykorystannya alhorytmiv diahnostyky skronevonyzhn'oshchelepnykh rozladiv [Reasoning for the use of temporo-mandibular disorder diagnostic algorithms]. Ukrainian Dental Almanac 2016;1(3):68-74.(in Ukrainian).

7. Bender ME, Lipin RB, Goudy SL. Development of the Pediatric Temporomandibular Joint. Oral Maxillofac Surg Clin North Am. 2018 Feb;30(1):1-9. doi: 10.1016/j.coms.2017.09.002.

\section{ТОПОГРАФОАНАТОМИЧЕСКИЕ ОСОБЕННОСТИ ВИСОЧНО-НИЖНЕЧЕЛЮСТНОГО СУСТАВА В ТРЕТЬЕМ ТРИМЕСТРЕ ВНУТРИУТРОБНОГО РАЗВИТИЯ И НОВОРОЖДЕН- НЫХ}

Резюме. Несмотря на определенный прогресс и интенсивное развитие стоматологических технологий, до сих пор существует множество невыясненных вопросов строения элементов зубочелюстной системы. Аномалии развития височно-нижнечелюстного сустава способствуют изменениям очертаний или развитию деформации лица, дегенерации или гипертрофии жевательных и мимических мышц, нарушают глотательные и жевательные движения, прикус или окклюзию. Исследование проведено на 19 препаратах плодов 301,0-450,0 мм теменно-пяточной длины и 6 препаратах новорожденных методами морфометрии и краниометрии, макро- и микропрепарирования, компьютерной томографии и статистического анализа. Большинство морфометрических параметров в динамике третьего триместра растет равномерно. Интенсивнее увеличиваются окружность головы - на 28-й, 29-й и 30-й неделе; длина черепа - на 28-й, 29-й и 35-й неделе; бипариетальный диаметр - на 30-31-й и 35-36-й неделе. Большинство краниометрических параметров у новорожденных увеличиваются равномерно. Несколько интенсивнее 
увеличивается окружность головы на 38-й неделе. У новорожденных височно-нижнечелюстной сустав приобретает дефинитивных черт строения, характеризуется наличием незначительно вогнутой суставной ямки и выраженного суставного бугорка. В раннем неонатальном периоде наблюдается увеличение всех краниометрических показателей, что свидетельствует о наращивании общей костной массы черепа, нижней челюсти и увеличении размеров височно-нижнечелюстного сустава. Дальнейшее изучение височно-нижнечелюстного сустава поспособствует верификации данных полученных путем УЗИ, КТ, МРТ, а также может служить основой для определения критических периодов в развитии лицевой области черепа плода человека.

Ключевые слова: височно-нижнечелюстной сустав; третий триместр; новорожденные; анатомия.

\section{TOPOGRAPHIC-ANATOMICAL PECULIARITIES OF THE TEMPOROMANDIBULAR JOINT IN THE THIRD TRIMESTER OF THE INTRAUTERINE DEVELOPMENT AND NEONATES}

Abstract. In spite of a certain progress and intensive development of dental technologies there are a number of unsolved issues concerning the dentoalveolar system structures. A considerable number of publications in scientific literature dealing with various aspects of dental anatomy still do not sufficiently study age anatomy and morphological preconditions promoting occurrence of temporomandibular joint pathology, irrespective of their important practical value. The study was conducted on 19 samples of fetuses 301,0-450,0 mm of the parietal-calcaneal length and 6 samples of neonates by means of the methods of morphometry and craniometry, macro- and micropreparation, computed tomography and statistical analysis. The majority of morphometric parameters in the dynamics of the third trimester increase evenly. More intensive increase can be detected concerning head circumference - on the 28th, 29th and 30th weeks; cranial length - on the 28th, 29th and 35th weeks; biparietal diameter - on the 30-31st and 35-36th weeks. The majority of craniometric parameters in neonates increase evenly. On the 38th week the head circumference increases more intensively. In neonates the temporomandibular joint becomes of a definite structure, is characterized by slightly concave articular fossa and pronounced articular tubercle. At the early neonatal period all the craniometric parameters increase which is indicative of enlargement of general osseous cranial mass, mandible and increasing the size of the temporomandibular joint. Further study of the temporomandibular joint will promote verification of the findings obtained by means of USD, CT, MRI, and will form the basis for detection of critical periods in the development of the facial part of the human cranium in fetuses.

Key words: temporomandibular joint, third trimester, neonates, anatomy.

\section{Відомості про авторів:}

Столяр Денис Борисович - кандидат медичних наук, асистент кафедри гістології, цитології та ембріології Вищого державного навчального закладу України “Буковинський державний медичний університет", м. Чернівці;

Слободян Олександр Миколайович - доктор медичних наук, професор, завідувач кафедри анатомії, топографічної анатомії та оперативної хірургії Вищого державного навчального закладу України “Буковинський державний медичний університет”, м. Чернівці;

Лаврів Леся Петрівна - кандидат медичних наук, старший викладач кафедри анатомії, топографічної анатомії та оперативної хірургії Вищого державного навчального закладу України “Буковинський державний медичний університет”, м. Чернівці;

Кавун Марина Павлівна - кандидат медичних наук, доцент кафедри анатомії людини імені М.Г. Туркевича Вищого державного навчального закладу України “Буковинський державний медичний університет", м. Чернівці.

Information about the authors:

Stoliar Denys B. - Candidate of Medical Science, Assistant of the Department of Histology, Cytology and Embryology of the Higher State Educational Establishment of Ukraine "Bukovinian State Medical University", Chernivtsi;

Slobodian Oleksandr M. - Doctor of Medical Sciences, Professor, chief of the Department of Anatomy, Topographic Anatomy and Operative Surgery of the Higher State Educational Establishment of Ukraine "Bukovinian State Medical University", Chernivtsi;

Lavriv Lesia P. - Candidate of Medical Science, Senior Lecturer of the Department of Anatomy, Topographic Anatomy and Operative Surgery of the Higher State Educational Establishment of Ukraine "Bukovinian State Medical University", Chernivtsi;

Kavun Maryna P. - Candidate of Medical Science, Assistant Professor of the Department of Human Anatomy named after M.G. Turkevich of the Higher State Educational Establishment of Ukraine "Bukovinian State Medical University", Chernivtsi. 